\title{
Standard method in production of maize inbreds of Lancaster germplasm
}

\author{
B. V. Dziubetskyi ${ }^{1}$, N. A. Bodenko ${ }^{1}$, V. Yu. Cherchel ${ }^{1 *}$, O. F. Stasiv² ${ }^{2}$ K. V. Denysiuk ${ }^{1}$, T. M. Satarova ${ }^{1}$ \\ ${ }^{1}$ State Enterprise Institute of Grain Crops of NAAS, 14 Volodymyr Vernadsky St, Dnipro, Ukraine, 49027 \\ ${ }^{2}$ Institute of Agriculture of Carpathian region of NAAS, 5 Grushevsky St, Obroshino, Lviv region, \\ Ukraine, 81115 \\ Corresponding authorE-mail:vlad cherch@ukr.net
}

Received: 05.12.2020. Accepted: 31.12.2020

\begin{abstract}
Aim. The article presents the results of selection of Lancaster maize lines by the standard method during 2006-2019.
Methods. The initial material was middle-ripe sister hybrid DK185×DK633-266 related to Lancaster (C103) germplasm. Its parental forms were the components of a number of hybrids listed in the State Register of Ukraine. Inbred DK633 (Lancaster C103 germplasm), closely related to inbred DK633-266 was taken as a control. The selection for a set of desirable features was made at each stage of self-pollination. Starting from the generation $S_{3}$, self-pollinated families were crossed with testers from alternative germplasms to estimate their combining ability.

Results. The maximum average grain yield of test crosses was recorded in $2011-10.97 \mathrm{t} \mathrm{ha}^{-1}$, the minimum - in dry year 2012 - $1.96 \mathrm{t} \mathrm{ha}^{-1}$. It was relatively low (4.45 t ha-1) in 2014; almost the same in 2010, 2015 and $2016-6.64,6.87$ and $6.54 \mathrm{t}$ ha ${ }^{-1}$, respectively; slightly higher in 2009, 2013 and $2017-7.60,7.77$ and $7.71 \mathrm{t} \mathrm{ha}^{-1}$, respectively; and the largest in $2019-8.84 \mathrm{t}$ ha ${ }^{1}$ and in 2018 - $9.16 \mathrm{t} \mathrm{ha}^{-1}$. The average grain moisture ranged from $11.8 \%$ in 2019 to $21.9 \%$ in 2009.

Conclusion. A group of maize constant lines has been selected ((DK185×DK633-266) 4pc12212111211, (DK185×DK633-266) 5pc4221311211, (DK185×DK633-266) 5pc4221311221, (DK185×DK633-266) 6pc131121111, (DK185×DK633-266) 6pc131121112, (DK185×DK633-266) 6pc131121121 and (DK185×DK633-266) 6pc2223111121)). The testcrosses of these lines exceeded in grain yield both testcrosses of inbred DK633 and standard hybrids by $0.5-1.5 \mathrm{t} \mathrm{ha}^{-1}$ at grain moisture at harvest lower by $2.0 \%$ or more. All of them have been included in crosses with the best testers of germplasms Reid, lodent and Mix for synthesis of new perspective hybrids FAO 300-400.
\end{abstract}

Keywords: selection; maize; line; test cross; grain yield and moisture

\section{Introduction}

Maize heterosis selection needs self-pollinated lines, which can be created from varieties-populations, hybrids, synthetic populations and varieties of exotic plasms (Andorf et al., 2019; Guo et al., 2013; Yu et al., 2020). A number of methods is used, depending on the objectives of a breeding program: standard, cumulative selection, pedigree, periodic selection, tissue culture, haploidy, induced mutagenesis, combined SSD and others. The development of the basic breeding principles and methods for production self-pollinated maize lines rightfully belongs to G. H. Shull (Shull GH 1909) and E. M. East (East EM, 1936). Their researches had formed the basis of the standard method for obtaining maize lines, and eventually to the synthesis of modern maize hybrids (Dzyubetskyy et al., 2012; Jugenheimer, 1979; Parsons et al., 2020; Yong et al., 2019; Yu et al., 2020). It is the most common in breeding practice and uses the selection of the desired genotypes in all successive generations of self-pollination until the achievement of homozygous state. In generations S1-S3, the selection is usually carried out according to the morphology of plants and ears. Subsequently (starting with S4) the combining ability of self-pollinated families in test crosses has to be determined. Some breeders investigate the combining ability of self-pollinated families starting even with S1 (early testing). The question about self-pollinated generation when it is appropriate to begin the assessment of combining ability still remains controversial. Although in practice, both early and late (>S3) testings depending on the objectives and scope of breeding programs are common (Fan X-M et al 2018, Jugenheimer RW 1979, Tilahun B et al 2019).

In the modern breeding of self-pollinated maize lines the most widely used initial material belongs to germplasms Lancaster, Reid and lodent. Lancaster germplasm originates from the free-pollinated variety Lancaster Sure Crop from the American corn belt and combines a number of elite lines of American selection such as $\mathrm{C} 103, \mathrm{Mo17}, \mathrm{OH} 40, \mathrm{OH} 43$ and their versions. The most common representatives of this germplasm are: middle-ripe inbred Oh43 and late-ripe inbred - Mo17 (C103). They are 
characterized with intensive initial growth, medium drought and heat resistance, medium resistance to common corn smut (Ustilago maydis) and high resistance to head smut (Sorosporium reilianum), tolerance to stem rot and leaf diseases. Plants are medium or tall, the ear is long. Grains are dent, yellow. High combining ability is found in crosses with lines of germplasms Reid and lodent (Czembor et al., 2019; Derkach et al., 2017; Mehl et al., 2020; Sokolov et al., 1999).

The research objective was to estimate and select Lancaster germplasm initial material with a wide adaptive potential to expand and optimize the heterozygous composition of FAO 300-500 hybrids with stable yield and low grain moisture content.

\section{Materials and Methods}

The researches were conducted in 2006-2019 at the State Enterprise "Experimental Farm "Dnipro" of the State Enterprise "Institute of Grain Crops" of NAAS according to generally accepted methods. The initial lines were studied in breeding nursery, and hybrids - in control nursery. Sowing was carried out in the second half of the third decade of April. The square of the plots was $4.9 \mathrm{~m}^{2}$, the repetition was three times. Plant density was formed as 50 thousand plants per hectare.

Weather conditions in the years of the researches were not uniform. Most of them were characterized with optimal temperatures and sufficient rainfall for growth and development of maize plants. Years 2010 and $2014-2016$ should be noted as drier, and 2012 as stressful. The average air temperature exceeded the climatic norm by $1.6^{\circ} \mathrm{C}$. In the critical period for the development of maize, it was higher by $1.7^{\circ} \mathrm{C}$ (July) and $2.6^{\circ} \mathrm{C}$ (August) above the average long-term norm. In 2012, abnormally high temperatures were observed in July, in average $25.5^{\circ} \mathrm{C}$ at climatic norm of $21.3^{\circ} \mathrm{C}$.

The distribution of precipitation by months was uneven. Their significant number fell in the form of downpours with hail and were unproductive. In addition, it resulted in lodging and damage to plants, which negatively affected the level of grain yield. The highest amount of precipitation was recorded in 2014 - 442.7 mm, the minimum one in 2013 - $193.1 \mathrm{~mm}$, with a long-term average amount $-272.0 \mathrm{~mm}$.

Initial material was represented with lines obtained via self-pollination of hybrid DK185×DK633-266, Lancaster germplasm (C103). Hybrid DK185×DK633-266 has been synthesized from the parental forms which were balanced on the basic economically valuable features and concentrated many desirable indicators in their genotype. Inbred DK633 (Lancaster C103 germplasm), which was closely related to inbred DK633-266 was taken as a control for testing the initial material.

For creating inbreds the standard method was used according to the following scheme:

Year 1. Self-pollination of 150 F1 plants of the initial population. The removal of plants and ears with undesirable traits.

Year 2. The cultivation of 25-30 plants from each self-pollinated ear on a separate plot. Self-pollination of up to 10 plants in each plot and selection of the best ones according to the program.

Year 3. Seed sowing from 3-5 ears of each selected plot. Self-pollination of desired plants. Selection of the best plots and 3-5 ears from each of them.

For the removal of plants in first three years the primary attention was paid to traits that were easily determined: the duration of developmental phases, plant height and ear attachment height, synchronous flowering of male and female inflorescences, pollen capacity, tightness and length of ear husks, root and stem lodging, the degree of disease and pest damage, plant remontancy, individual plant productivity and the evenness of ears.

A rather large volume of inbred families' removal made it possible to pay attention on more valuable initial materials and form a competitive product already in generations S6-S7. A. F. Troyer points to the high efficiency of selection with 60-75\% removal of self-pollinated families at the stages S2-S4 and the possibility to free up to 30\% of areas (Troyer, 2000).

Year 4. Families S3 selected by phenotype in a previous year are cultivated in separate rows of breeding nursery and selfpollination of 3-4 ears to obtain seeds of generation S4. The removal of undesirable families and intrafamily plant selection on breeding valuable traits; each family testing with 2-3 testers from alternative germplasms.

Year 5. Testing of test crosses for families S3 in the control nursery and their estimation on economically valuable indicators (grain yield, grain moisture at harvest, resistance to lodging, the dates of tassel and ear flowering, etc.). According to the results of testing, 20-25 best families were selected. Families S4 selected by phenotype in previous years were cultivated in separate rows of breeding nursery; self-pollination of 3-4 ears to obtain seeds of generation S5. The eradication of undesirable families; intrafamily selection of plants on breeding valuable traits; family testing with 3-4 testers from alternative germplasms.

Year 6. Testing of test crosses of families S4 in a control nursery and their estimation on economically valuable parameters just like test crosses of families S3. According to the test results, 20-25 best families were selected. Then families S5 selected by phenotype in a previous year are cultivated in separate rows of breeding nursery and self-pollination of 3-4 ears are made to obtain seeds of generation S6. The eradication of undesirable families; intrafamily selection of plants on breeding valuable traits; family testing with 3-4 testers from alternative germplasms.

Year 7. The assessment of test crosses of families S5 selected according to the results of the preliminary test in a control nursery. Estimation of hybrids on the main economically valuable characteristics. Selection of the best families $\mathbf{S 6}$ according to the results of test crosses assessments and the estimates per se in previous years. Self-pollination of 3-4 ears, obtaining seeds of families 57. Intrafamily selection of plants on a set of breeding valuable traits; family testing with 3-4 testers from alternative germplasms.

Year 8. Testing of test crosses of families S6, selected on the results of a preliminary test in a control nursery. Estimation of hybrids on economically valuable characteristics. Sowing of families S7, selected by the test results and estimates of previous years, in a breeding nursery. Intrafamily selection of plants according to breeding valuable features; testing with 5-6 testers from alternative germplasms. 
Year 9. The assessment of test crosses for selected inbreds in the nurseries of preliminary or competitive testing. Estimation of hybrids on a set of parameters. According to the test results, the best inbreds are propagated on areas for primary seed production.

Testers from various alternative germplasms were used to estimate the inbred material for combining ability. Hybrids Bystritsa 400 MB, Monika 350 MV (2009-2014), DN Hetera and DN Julia (2015-2019) which in different years had been enlisted in the State Register of Plant Varieties (Ukraine) were taken as standards for testing test crosses.

\section{Results}

The test crosses yields for families from different self-pollination generations indicate their significant dependence on weather conditions on a year of cultivation (Table 1). Over the years of research, the highest average yield was found for the test crosses of families S5 in $2011-10.97 \mathrm{t}$ ha-1, which was at the level of standard hybrid Bystritsa $400 \mathrm{MV}$ (10.95 t ha-1) and lower by 0.12 0.13 t ha-1 in comparison with standard hybrid Monika 350MV and test crosses of control inbred DK633. The range of variation was $3.41 \mathrm{t}$ ha-1 with a maximum value of $12.92 \mathrm{t}$ ha-1, which on average exceeded the standards by almost $1.9 \mathrm{t} \mathrm{ha}^{-1}$.

Table 1. Parameters of grain yield variation in test crosses of self-pollinated families for group DK185×DK633-266, $t$ ha ${ }^{-1}$

\begin{tabular}{|c|c|c|c|c|c|c|}
\hline Years & $\mathrm{M} \pm \mathrm{SD}$ & Lim (min-max) & $C V, \%$ & $\begin{array}{c}\text { Test crosses of } \\
\text { control inbred } \\
\text { DK633 } \\
\end{array}$ & $\begin{array}{c}\text { *Standard hybrid } \\
\text { Monika 350MV / } \\
\text { DN Julia }\end{array}$ & $\begin{array}{c}\text { *Standard hybrid } \\
\text { Bystritsa 400MV / } \\
\text { DN Hetera }\end{array}$ \\
\hline 2009 & $7.60 \pm 0.1$ & $6.56-8.82$ & 7.8 & 7.74 & 7.09 & 8.13 \\
\hline 2010 & $6.64 \pm 0.1$ & $5.27-7.88$ & 9.7 & 6.22 & 6.46 & 7.43 \\
\hline 2011 & $10.97 \pm 0.1$ & $9.51-12.92$ & 7.1 & 11.10 & 11.09 & 10.95 \\
\hline 2012 & $1.96 \pm 0.1$ & $1.37-2.64$ & 15.5 & 1.74 & 1.89 & 2.38 \\
\hline 2013 & $7.77 \pm 0.1$ & $6.13-8.85$ & 8.1 & 7.22 & 7.97 & 7.40 \\
\hline 2014 & $4.45 \pm 0.2$ & $3.57-5.29$ & 13.2 & 4.42 & 4.94 & 5.68 \\
\hline 2015 & $6.87 \pm 0.1$ & $6.21-7.48$ & 5.5 & 6.48 & 7.59 & 6.70 \\
\hline 2016 & $6.54 \pm 0.1$ & $5.91-7.12$ & 6.9 & 6.48 & 5.80 & 6.51 \\
\hline 2017 & $7.71 \pm 0.4$ & $7.22-8.87$ & 10.1 & 7.52 & 6.82 & 7.85 \\
\hline 2018 & $9.16 \pm 0.1$ & $8.74-9.84$ & 3.8 & 7.02 & 8.45 & 8.04 \\
\hline 2019 & $8.84 \pm 0.2$ & $7.61-9.73$ & 7.1 & 8.14 & 8.19 & 8.71 \\
\hline
\end{tabular}

*Hybrids Bystritsa 400 MB, Monika 350 MV (2009-2014), DN Hetera and DN Julia (2015-2019) which in different years had been enlisted in the State Register of Plant Varieties (Ukraine) were taken as standards for testing test crosses.

The minimum values of the average grain yield for test crosses $\left(1.96 \mathrm{t} \mathrm{ha}^{-1}\right)$ were recorded in the dry year of 2012. $9 \%$ of them exceeded standard hybrid Bystritsa $400 \mathrm{MV}$ by $0.18-0.26 \mathrm{t} \mathrm{ha}^{-1}$, and $6 \%$ of them were on its levels $\left(2.38 \mathrm{t} \mathrm{ha}^{-1}\right)$. Hybrid Monika $350 \mathrm{MV}$ provided the grain yield of $1.89 \mathrm{t} \mathrm{ha}^{-1}$, and testcrosses of DK633 demonstrated in average $1.74 \mathrm{tha}-1$.

Grain yield of testcrosses was relatively low in $2014\left(4.45 \mathrm{t} \mathrm{ha}^{-1}\right)$, almost the same in 2010, 2015 and $2016(6.64,6.87$ and $6.54 \mathrm{t}$ ha $^{-1}$, respectively), slightly higher in 2009, 2013 and 2017 (7.60, 7.77 and $7.71 \mathrm{t} \mathrm{ha}^{-1}$, respectively) while the largest in 2019 (8.84 $\left.\mathrm{t} \mathrm{ha}^{-1}\right)$ and in $2018\left(9.16 \mathrm{t} \mathrm{ha}^{-1}\right)$. Almost every year the average yield of test crosses of self-pollinated families S3-S7 was close to its values for the standard hybrids and test crosses of control inbred DK633. But it was much higher compared to them on maximum yield values in the best families. Coefficients of variation indicate a small range of yield in most years, i.e. the efficiency of selection was quite high.

Particular attention in the selection of maize grain hybrids is paid to moisture, taking into account that the post-harvest grain processing requires significant material costs (Martinez-Feria et al., 2019; Zhang et al., 2016, 2020). Both external factors and genotype of a plant can play a decisive role in the manifestation degree of "harvesting grain moisture". The nature of grain moisture loss during ripening is crucial for the results (Zhang et al., 2020).

In our studies, the lowest average grain moisture at harvest (11.8\%) was observed in 2019, which was by $4.5 \%$ lower than in the test crosses of inbred DK633 and by 3.2\%. lower than in standard hybrid DN Hetera (Table 2).

The average grain moisture of test crosses of families S3 was slightly higher in 2012 and amounted to $12.7 \%$, which was at the level of standard hybrids; the range of variation was from $11.4 \%$ to $15.7 \%$. The wettest grain at harvest was cropped in 2009. The average population value of this parameter for test crosses (21.9\%) was 1\% lower than for test crosses of inbred DK633 (22.9\%). Its levels in standard hybrids Monika 350MV and Bystritsa 400MV were 20.8\% and 20.5\% respectively. Approximately $16 \%$ of test crosses had grain moisture content of $20.5-20.7 \%$ while $9 \%$ of test crosses had it ranged from 19.5 to $20.0 \%$. At the beginning of the work, the initial breeding material was divided into 6 subgroups and the selection on a set of traits was made at each self-pollination stage. It determined various portions of undesired families removal in each subgroup. In all subgroups hybrid combinations were selected that were the best on the trait "grain yield". Table 3 presents the selection dynamics on the example of self-pollinated families in subgroup 4.

The constant (S8) inbreds have been originated in all subgroups: (DK185×DK633-266) 4pc12212111211, (DK185×DK633-266) 5pc4221311211, (DK185×DK633-266) 5pc4221311221, (DK185×DK633-266) 6pc131121111, (DK185×DK633-266) 6pc131121112, (DK185×DK633-266) 6pc131121121 and (DK185×DK633-266) 6pc2223111121. Their testcrosses exceeded both DK633 testcrosses and standard hybrids in grain yield by 0.5-1.5 tha-1 at grain humidity at harvest lower by $2.0 \%$ and more. All of them have been included in crosses with 8-10 testers of alternative germplasms (Reid, lodent and Mix) for a wide assessment and production of promising FAO 300-400 hybrids. 
Table 2. Parameters of grain moisture variation in test crosses of self-pollinated families for group DK185×DK633-266, $\%$.

\begin{tabular}{|c|c|c|c|c|c|c|}
\hline Years & $\mathrm{M} \pm \mathrm{SD}$ & Lim (min-max) & $C V, \%$ & $\begin{array}{l}\text { Test crosses } \\
\text { of control } \\
\text { inbred DK633 }\end{array}$ & $\begin{array}{c}\text { *Standard hybrid } \\
\text { Monika 350MV / } \\
\text { DN Julia }\end{array}$ & $\begin{array}{c}\text { *Standard hybrid } \\
\text { Bystritsa 400MV / } \\
\text { DN Hetera }\end{array}$ \\
\hline 2009 & $21.9 \pm 02$ & $19.5-24.6$ & 5.8 & 22.9 & 20.8 & 20.5 \\
\hline 2010 & $19.6 \pm 0.3$ & $15.1-24.3$ & 11.1 & 21.4 & 15.0 & 21.3 \\
\hline 2011 & $17.3 \pm 0.1$ & $16.2-19.0$ & 3.9 & 17.4 & 17.3 & 16.4 \\
\hline 2012 & $12.7 \pm 0.2$ & $11.4-15.7$ & 7.1 & 12.5 & 12.1 & 12.8 \\
\hline 2013 & $19.4 \pm 0.1$ & $18.7-19.8$ & 1.5 & 19.6 & 20.6 & 18.9 \\
\hline 2014 & $14.5 \pm 0.1$ & 13.7-15.2 & 3.0 & 14.2 & 14.2 & 14.7 \\
\hline 2015 & $14.5 \pm 0.3$ & $13.2-15.4$ & 5.1 & 13.7 & 14.0 & 14.4 \\
\hline 2016 & $17.9 \pm 0.6$ & $15.2-20.5$ & 10.2 & 17.0 & 17.8 & 19.6 \\
\hline 2017 & $17.8 \pm 1.0$ & $15.2-20.0$ & 11.3 & 16.3 & 15.2 & 15.9 \\
\hline 2018 & $14.6 \pm 0.5$ & $12.0-17.1$ & 10.8 & 11.6 & 13.0 & 14.0 \\
\hline 2019 & $11.8 \pm 0.4$ & $9.2-15.6$ & 12.6 & 16.3 & 14.4 & 15.0 \\
\hline
\end{tabular}

*Hybrids Bystritsa 400 MB, Monika 350 MV (2009-2014), DN Hetera and DN Julia (2015-2019) which in different years had been enlisted in the State Register of Plant Varieties (Ukraine) were taken as standards for testing test crosses.

Table 3. The average yield and grain moisture of test crosses of self-pollinated families for subgroup 4 of group (DK185×DK633266).

\begin{tabular}{|c|c|c|c|c|c|c|c|c|c|}
\hline \multirow[t]{2}{*}{ Years } & \multirow[t]{2}{*}{ Generation } & \multirow[t]{2}{*}{$\begin{array}{l}\text { Grain } \\
\text { yield, } \\
\text { t ha-1 }\end{array}$} & \multirow[t]{2}{*}{$\begin{array}{c}\text { Grain } \\
\text { moisture,\% }\end{array}$} & \multicolumn{2}{|c|}{$\begin{array}{c}\text { Test crosses of } \\
\text { control inbred } \\
\text { DK633 }\end{array}$} & \multicolumn{2}{|c|}{$\begin{array}{c}\text { **Standard } \\
\text { hybrid Monika } \\
\text { 350MV / DN Julia }\end{array}$} & \multicolumn{2}{|c|}{$\begin{array}{c}\star \star \text { Standard } \\
\text { hybrid Bystritsa } \\
\text { 400MV / DN } \\
\text { Hetera }\end{array}$} \\
\hline & & & & $1 *$ & $2 *$ & $1 *$ & $2 *$ & $1 *$ & $2 *$ \\
\hline 2009 & 4 рс 12 & 7.81 & 21.1 & 7.74 & 22.9 & 7.09 & 20.8 & 8.13 & 20.5 \\
\hline 2010 & 4 рс 122 & 7.88 & 19.9 & 6.22 & 21.4 & 6.46 & 15.0 & 7.43 & 21.3 \\
\hline 2011 & 4 рс 1221 & 12.92 & 17.1 & 11.1 & 17.4 & 11.09 & 17.3 & 10.95 & 16.4 \\
\hline 2012 & 4 рс 12211 & 2.17 & 12.4 & 1.74 & 12.5 & 1.89 & 12.1 & 2.38 & 12.8 \\
\hline \multirow[t]{2}{*}{2013} & 4 pc 122111 & 7.93 & 19.8 & 7.22 & 19.6 & 7.97 & 20.6 & 7.40 & 18.9 \\
\hline & 4 рс 122121 & 8.70 & 19.7 & & & & & & \\
\hline \multirow[t]{2}{*}{2014} & 4 рс 1221111 & 4.48 & 14.2 & 4.42 & 14.2 & 4.94 & 14.2 & 5.68 & 14.7 \\
\hline & 4 рс 1221211 & 5.12 & 14.9 & & & & & & \\
\hline \multirow[t]{3}{*}{2015} & 4 рс 12211111 & 6.96 & 14.0 & 6.48 & 13.7 & 7.59 & 14.0 & 6.70 & 14.4 \\
\hline & 4 рс 12211113 & 6.99 & 14.6 & & & & & & \\
\hline & 4 рс 12212111 & 6.90 & 14.6 & & & & & & \\
\hline \multirow[t]{2}{*}{2016} & 4 рс 122111131 & 6.96 & 19.6 & 6.48 & 17.0 & 5.80 & 17.8 & 6.51 & 19.6 \\
\hline & 4 рс 122121112 & 6.83 & 19.3 & & & & & & \\
\hline \multirow[t]{2}{*}{2017} & 4 рс 1221111111 & 7.29 & 17.4 & 7.52 & 16.3 & 6.82 & 15.2 & 7.85 & 15.9 \\
\hline & 4 рс 1221111311 & 7.22 & 15.2 & & & & & & \\
\hline \multirow[t]{3}{*}{2018} & 4 рс 12211111111 & 9.84 & 15.9 & 7.02 & 11.6 & 8.45 & 13.0 & 8.04 & 14.0 \\
\hline & 4 рс 12211113111 & 9.17 & 17.1 & & & & & & \\
\hline & 4 рс 1221211121 & 9.09 & 15.5 & & & & & & \\
\hline \multirow[t]{2}{*}{2019} & 4 рс 122111131111 & 8.88 & 15.6 & 8.14 & 16.3 & 8.19 & 14.4 & 8.71 & 15.0 \\
\hline & 4 рс 12212111211 & 9.52 & 11.8 & & & & & & \\
\hline
\end{tabular}

1 * -grain yield, t ha-1, 2* -grain moisture,\%. **Hybrids Bystritsa 400 MB, Monika 350 MV (2009-2014), DN Hetera and DN Julia (2015-2019) which in different years had been enlisted in the State Register of Plant Varieties (Ukraine) were taken as standards for testing test crosses.

We observed a rather high $(r=0,683)$ dependence of the combining ability level in successive self-pollination generations on its value in the initial families. This fact indicates the need for careful initial families screening by this parameter in the early stages of self-pollination.

The research effectiveness has been confirmed by the grain yield and grain moisture in test crosses of the best S8 families in 2019 as compared to standard hybrids and test crosses of control inbred DK633 (Table 4). The grain yield excess in test crosses of families S8 over the best standard hybrid ranged from 14.0 to $25.3 \%$, with moisture lower by 1.3-8.9\%.

Hybrid combinations DK4435×(DK185×DK633-266) 6pc131121111, DK5002× (DK185×DK633-266) 6pc131121121, DK5002×(DK185×DK633-266) 5pc4221311211, DK5002× (DK185×DK633-266) 5pc4221311221 and DK5002× (DK185×DK633266) 6 pc131121112 should be emphasized as they demonstrated grain yield over $10.0 \mathrm{t}$ ha-1 and grain moisture at harvest from 6.1 to $11.5 \%$. 
Table 4. Grain yield and grain moisture of test crosses of the best self-pollinated lines from the group (DK185×DK633-266), in 2019.

\begin{tabular}{|c|c|c|}
\hline Test crosses & Grain yield, $\mathrm{t} \mathrm{ha}^{-1}$ & Grain moisture, $\%$ \\
\hline DK4435×(DK185×DK633-266) 6pc131121111 & 10.91 & 11.5 \\
\hline DK5002×(DK185×DK633-266) 6pc131121121 & 10.55 & 6.1 \\
\hline DK5002×(DK185×DK633-266) 5pc4221311211 & 10.16 & 7.4 \\
\hline DK5002×(DK185×DK633-266) 5pc4221311221 & 10.12 & 6.8 \\
\hline DK5002×(DK185×DK633-266) 6pc131121112 & 10.11 & 6.2 \\
\hline DK3642×(DK185×DK633-266) 6pc131121111 & 9.99 & 10.3 \\
\hline DK3642×(DK185×DK633-266) 4pc12212111211 & 9.97 & 12.6 \\
\hline DK4168×(DK185×DK633-266) 6pc131121121 & 9.97 & 12.1 \\
\hline DK5002×(DK185×DK633-266) 6pc2223111121 & 9.96 & 9.3 \\
\hline DK4168×(DK185×DK633-266) 5pc4221311221 & 9.93 & 12.7 \\
\hline Test crosses of control inbred DK633 & 8.14 & 16.3 \\
\hline Standard hybrid DN Julia & 8.19 & 14.4 \\
\hline Standard hybrid DN Hetera & 8.71 & 15.0 \\
\hline LSD 0.05 & 0.7 & 2.5 \\
\hline
\end{tabular}

The best self-pollinated lines from the group (DK185×DK633-266) have the duration of period from seed germination to ear flowering of 50 days which is by 6-10 days shorter compared to control inbred DK633 (Table 5). The plant height varies from 148 to $160 \mathrm{~cm}$ with the ear attachment height from 40 to $55 \mathrm{~cm}$. Resistance to lodging is high. Resistance to major diseases is high. Ears are cylindrical, 15-19 cm long. The cob colour of the lines is red, except for (DK185×DK633-266) 4pc12212111211, in which the cob is white. Grains are flinty-dent (f/d) and dent-flinty (d/f), yellow. The grain number in a row - 18-28, the number of grain rows per ear - 8-12. The weight of 1000 grains is 258-360 g. The combining ability is high.

Table 5. Features of the best self-pollinated lines from the group (DK185×DK633-266), in 2019.

\begin{tabular}{|c|c|c|c|c|c|c|c|c|c|}
\hline $\begin{array}{l}\text { Self-pollinated lines } \\
\text { from the group } \\
\text { (DK1 85×DK633-266) }\end{array}$ & $\begin{array}{c}\text { Number of } \\
\text { days from } \\
\text { germination to } \\
\text { ear flowering }\end{array}$ & $\begin{array}{l}\text { Plant } \\
\text { height, } \\
\text { cm }\end{array}$ & $\begin{array}{c}\text { Height of } \\
\text { ear } \\
\text { attachment, } \\
\mathrm{cm} \\
\end{array}$ & $\begin{array}{l}\text { Ear } \\
\text { length, } \\
\mathrm{cm}\end{array}$ & $\begin{array}{l}\text { Cob } \\
\text { color }\end{array}$ & $\begin{array}{c}\text { Grain } \\
\text { consistency }\end{array}$ & $\begin{array}{l}\text { Number } \\
\text { of grains } \\
\text { per a } \\
\text { row, pcs }\end{array}$ & $\begin{array}{l}\text { Number } \\
\text { of grain } \\
\text { rows, pcs }\end{array}$ & $\begin{array}{c}\text { Thousan } \\
\text { seeds } \\
\text { weight, } \varepsilon\end{array}$ \\
\hline $4 p c 12212111211$ & $70-72$ & 154 & 50 & 18 & white & $f / d$ & $18-20$ & $8-12$ & 330 \\
\hline $5 p c 4221311211$ & $72-73$ & 152 & 40 & $18-19$ & red & $f / d$ & 18 & $10-12$ & 280 \\
\hline $5 p c 4221311221$ & $69-71$ & 157 & 45 & $17-19$ & red & $f / d$ & $16-22$ & $8-10$ & 276 \\
\hline $6 p c 131121111$ & $72-73$ & 160 & 55 & $15-17$ & red & $d / f$ & $20-24$ & 10 & 336 \\
\hline $6 p c 131121112$ & $73-76$ & 155 & 50 & $15-17$ & red & $d / f$ & $18-26$ & $8-10$ & 276 \\
\hline $6 p c 131121121$ & $72-76$ & 148 & 45 & $16-17$ & red & $d / f$ & $20-26$ & $8-10$ & 360 \\
\hline $6 p c 2223111121$ & $68-70$ & 151 & 40 & $17-18$ & red & $d / f$ & $20-28$ & 10 & 258 \\
\hline DK633 & $79-82$ & 154 & 50 & $15-20$ & red & $d / f$ & $20-28$ & $8-10$ & 245 \\
\hline
\end{tabular}

\section{Discussion}

Breeding companies and institutions are permanently working on the collection of germplasms adapted to the specific conditions of a region where the selection takes place. For this reason, the collected elite assortment reflects the characteristic features inherent in the accommodation of plants, manifested in counteracting the stresses of the region. The history of selection changes in genetic diversity, starting from ancestral forms, not only reflects the predilections of a scientist, the creative handwriting or the tribute to fashion trends. It demonstrates the priority criteria of a formed pool under the influence of various natural factors of the selective environment. Implementation of an inbreeding program for the synthesis of new initial material in cumulative and recurrent selection involves the creation of special hybrid combinations with the participation of the best elite maize lines. A small number of basic elite inbreds allows to create a significant number of different hybrid combinations that respond differently to self-pollination, which is proved true by the results of other authors (Yong et al., 2019). According to our data, hybrid combinations with high combining ability on "grain yield" allow to obtain on their basis self-pollinated lines which are best on this trait. This is confirmed in different breeding programs performed in various climatic conditions (Fan et al., 2018; Martinez-Feria et al., 2019; Tilahun et al., 2019).

The probability of positive results in obtaining selection hybrids can be predicted through their estimates of GCA and the level of grain yield in test crosses. However, a lot of factors: the influence of a tester, the conditions of a year, the initial material, make it difficult to identify clearly promising forms for further creation of new inbred progeny. To overcome the relevant obstacles, it is important to determine the tester and take into account the assessments of test crosses only in favorable or middle intensity of stress factors. The rapid development of maize selection has led to the improvement of methodological techniques and basic selection schemes (Andorf et al., 2019). The trend of world selection is optimization, and sometimes a fundamental revision of traditional heterosis models based on common germplasms (Yu et al., 2020). During the period of our 
researches, heterosis models of hybrids on the basis of lodent $\times$ Lancaster and BSSS $\times$ Lancaster models were also modernized by creating new versions of a male parental form those met the requirements of grain production in Ukraine.

The formation of a new basic collection of medium-ripe and medium-late Lancaster lines for heterosis selection has led to moving genetically in side from the main ancestral components, which is evidenced by the allelic status of molecular markers of single nucleotide polymorphism (Derkach et al., 2017). In our opinion, this process is associated with adaptation to the stressful conditions of the Steppe zone due to the acquisition of such qualities as high drought resistance, heat resistance, the formation of low grain moisture at harvest. Such evolution of the breeding material leads to the initiation and development of a new genealogical branch of dent genotypes of the southern ecotype of maize.

\section{Conclusion}

Several inbred lines have been produced which are better than initial forms by the set of traits; their test crosses exceed the standard hybrids in grain yield (by 14-25\%) at a lower moisture (by $2.0 \%$ and more). The obtained inbred lines are widely used in selection of drought- and heat-resistant maize hybrids with a wide adaptive potential, capable to provide stable and high yields with low grain moisture at harvest.

\section{Acknowledgements}

The work was performed in accordance with the problem "To develop scientific principles for the creation of maize initial material and the synthesis of hybrids (FAO 150-300) of different directions of utilization for the conditions of all soil and climatic zones of Ukraine" (14.01.00.01.F, No 0116U001238) PSI 14 "To develop an agroecological complex of increasing the productivity of grain crops on the basis of the latest advances in breeding and resource-adaptive models of technologies for different agricultural areas ("Technologies for cultivation of cereals. Selection of maize and sorghum") subprogram 01 " Scientific basis of creation of initial material and high productive hybrids of maize and sorghum with high adaptive characteristics "("Breeding and seed production of maize and sorghum

\section{References}

Andorf C., Beavis W.D., Hufford M. (2019). Technological advances in maize breeding: past, present and future. Theor Appl Genet, 132(3), 817849. doi:10.1007/s00122-019-03306-3

Czembor E., Waśkiewicz A., Piechota U. (2019). Differences in ear rot resistance and Fusarium verticillioides-produced fumonisin contamination between Polish currently and historically used maize inbred lines. Front Microbiol, 10, 449. doi:10.3389/fmicb.2019.00449

Derkach K.V., Satarova T.M., Borysova V.V. (2017). Grouping and clustering of maize Lancaster germplasm inbreds according to the results of SNP-analysis. Regulatory Mechanisms in Biosystems, 8(3), 343-348 (in Ukrainian). doi:10.15421/021753

Dzyubetskyy B.V., Bodenko N.A., Fedko M.M. (2012). Creating the middlelate maize hybrids based on plasma Lancaster (C103). Bulletin Institute of agriculture of steppe zone NAAS of Ukraine, 3, 8-1 (in Ukrainian)

East EM (1936) Heterosis. Genetics, 21, (4)375-397

Fan X.- M., Zhang Y.- D., Jeffers D. (2018). Combining ability of yellow lines derived from CIMMYT populations for use in subtropical and tropical midaltitude maize production environments. Crop Science, 58, 169-179. doi:10.2135/cropsci2017.05.0291

Guo T., Li H., Yan J. (2013). Performance prediction of F1 hybrids between recombinant inbred lines derived from two elite maize inbred lines. Theor Appl Genet, 126(1), 189-201. doi:10.1007/s00122-012-1973-9

Jugenheimer R.W. (1979). Corn: Improvement, seed production, and uses. Kolos, Moscow (in Russian).

Martinez-Feria R.A., Licht M.A., Ordóñez R.A. (2019). Evaluating maize and soybean grain dry-down in the field with predictive algorithms and genotype-by-environment analysis. Sci Rep, 9(1), 7167. doi:10.1038/s41598-019-43653-1

Mehl K.M., Mikel M.A., Bradley C.A. (2020). Evaluation of corn germplasm accessions for resistance to Clavibacter nebraskensis, causal agent of Goss's bacterial wilt and leaf blight. Plant Dis. doi:10.1094/PDIS-11-19-2394-RE.

Parsons L., Ren Y., Yobi A. (2020). Production and selection of quality protein popcorn hybrids using a novel ranking system and combining ability estimates. Front Plant Sci, 11, 698. doi:10.3389/fpls.2020.00698

Shull G.H. (1909). A pure line method of corn breeding. Journal of Heredity, 5(1), 51-58.

Sokolov V.M., Varenyk B.F., Pilyugin A.S. (1999). Breeding evaluation of elite self-pollinated corn lines from the main heterotic germplasm groups. In: Genetics, breeding and technology of corn cultivation. Kniish, Krasnodar, pp. 92-96 (in Rusian)

Tilahun B., Azimach G., Keno T. (2019). Test cross performance and combining ability of newly introduced quality protein maize (Zea mays) inbred lines for grain yield and agronomic traits evaluated in mid-altitude agro-ecological zones of Ethiopia, South African. Journal of Plant and Soil, 36(3), 173-180. doi:10.1080/02571862.2018.1537009

Troyer A.F. (2000). Temperate corn - background, behavior, and breeding. In: Hallauer AR (ed.) Specialty corns. CRC Press, Boca Raton, FL, pp. 393-466

Yong H., Zhang F., Tang J. (2019). Breeding potential of inbred lines derived from five maize (Zea mays L.) populations Euphytica. Netherlands J of Plant Breeding, 215(1), 1. doi:10.1007/s10681-018-2319-8

Yu K., Wang H., Liu X. (2020). Large-scale analysis of combining ability and heterosis for development of hybrid maize breeding strategies using diverse germplasm resources. Front Plant Sci, 11, 660. doi:10.3389/fpls.2020.00660

Zhang H.L., Ma Q., Fan L.F. (2016). Nondestructive in situ measurement method for kernel moisture content in corn ear. Sensors (Basel), 16(12), 2196. doi:10.3390/s16122196

Zhang J., Zhang F., Tang B. (2020). Molecular mapping of quantitative trait loci for grain moisture at harvest and field grain drying rate in maize (Zea mays L.). Physiol Plantarum, 169, 64-72. doi:10.1111/ppl.13048

\section{Citation:}

Dziubetskyi, B.V., Bodenko, N.A., Cherchel, V.Yu., Stasiv, O.F., Denysiuk, K.V., Satarova, T.M. (2020). Standard method in production of maize inbreds of lancaster germplasm. Ukrainian Journal of Ecology, 106), 88-93.

(cc) EY This work is licensed under a Creative Commons Attribution 4.0. License 